\title{
Local scour around complex pier groups and combined piles at semi-integral bridge
}

\author{
Shatirah Akib*, Afshin Jahangirzadeh, Hossein Basser \\ Department of Civil Engineering, University of Malaya, 50603 Kuala Lumpur, Malaysia. \\ *Corresponding author. E-mail: shatirah@um.edu.my; afshin.jk@gmail.com
}

\begin{abstract}
This research presents an experimental study on the scouring mechanism at semi-integral bridge piers. Based on laboratory experiments, this study focuses on the relationship between scour depth in complex pier groups and combined piles bridge and various parameters including the variation of inflow velocity, distance, and time. 1200 data were collected for flow velocity and scour. The flow pattern and scour were analyzed for different flow discharges and flow depths. The results showed that the scour development with respect to time was greater for higher flow depth and bigger flow discharge at semi-integral bridges. In addition, the equilibrium scour depth increased with the approach flow depth around piers at semi-integral bridges. Velocity distribution also affected the scour development. It decreased when approaching the bridge but increased from upstream to downstream of the flume.
\end{abstract}

Keywords: Semi-integral Bridge; Complex pier groups; Combined Piles; Scour; Pier; Scour Depth.

\section{INTRODUCTION}

Bridges play a vital role in the transportation of goods and services. Bridges, which are built by the modern system, are more cost-effective. Semi-integral bridges are popular in Malaysia (Fig. 1). In these simple or multiple span bridges, the superstructure is cast integrally on top of the substructure and discontinuous to other parts of the substructure (England et al., 2000). The advantage of this type of bridge is reduction in initial construction cost, long-term maintenance expenses, substructure design, resistance to accidental and seismic loadings, torsional restraint of deck at support, faster construction, reduced tolerance requirements, and greater end span ratio ranges (Akib et al., 2011a, b, c, d; Biddle et al., 1997). This advantage has made semi-integral bridges an alternative solution; many of these bridges have been constructed in Malaysia during the past few years.

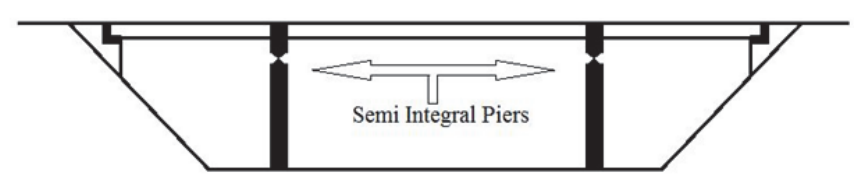

Fig. 1. Schematic view of semi-integral bridge.

However, this new system is relatively unknown in account for the effect of design factors on natural hazards and local weather as well as environmental condition. An example is the effect of floods on bridges. There are reports of surface run-off due to flood that exceeded the capacities of most rivers in Malaysia back in the 1920s (Fig. 2). Therefore, investigating of the effect of flood on semi-integral bridges is important. One of the most destructive effects of floods is scouring.

The flow pattern and mechanisms of scouring are very complicated, and the complexity of flow increases with the development of the scour hole (Ghodsian and Vaghefi, 2009). The basic mechanism causing local scour at piers is the down-flow at the upstream face of the pier and the formation of the horseshoe vortex at the base of the pier. The down-flow is believed to be the primary cause of scour at piers. The horseshoe vortex that develops due to the separation of flow at the edge of the scour hole upstream rolls to form a helical flow, which is similar to the ground roller downstream of a dune crest. The horseshoe vortex is a consequence of scour, not the primary cause, pushing the down-flow inside the scour hole closer to the pier. Separation of the flow at the sides of the pier also creates socalled wake vortices. These vortices are unstable and shed disorderly from each side of the pier. They act as small tornadoes lifting the sediment from the bed to form a scour hole downstream of the pier (Akib et al., 2014; Akib et al., 2012; Heidarpour et al., 2010; Zarrati et al., 2006;). Fig. 3 shows the flow and scour pattern at a circular pier.

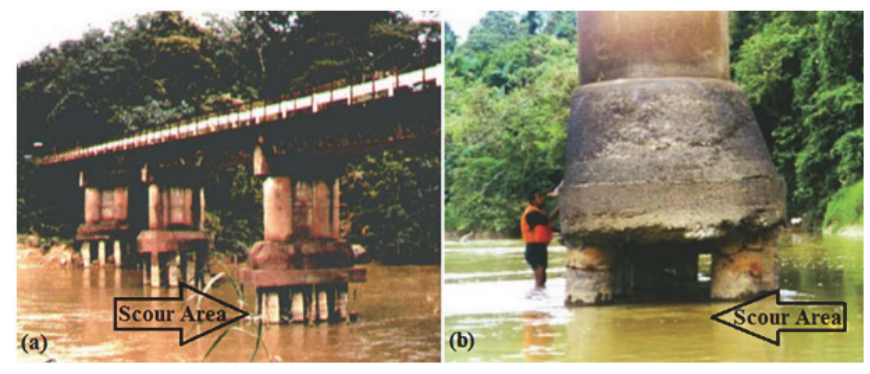

Fig. 2. Scour at (a) Sungai Muda Bridge, Malaysia, (b) Sungai Jeniang Bridge, Malaysia.

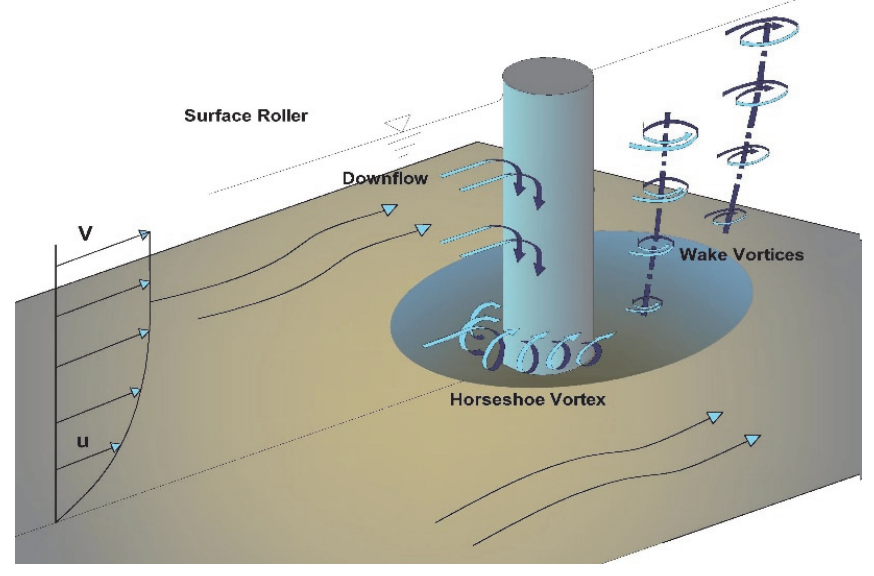

Fig. 3. Flow and scour pattern around a circular pier. 
For live-bed scour, scouring ceases when equilibrium is reestablished between the material inflow and outflow. For clearwater scour, scouring ceases when the horseshoe vortex scour shear stress equals the sediment particle at the scour hole shear stress, thereby reducing the transport rate from the base region (Lagasse et al., 2007; Picek et al., 2004; Pagliara and Carnacina, 2010).

Bridge scour is an unusual changing movement that varies with factors such as water depth, flow angle and intensity, pier and abutment's shape and dimension and material properties (Deng and Cai, 2010). Factors that influence the size of the local scour depth at piers (Lagasse et al. 2001) include: approach flow velocity, flow depth, pier width, gravitational acceleration, pier length if skewed to the main flow direction, size and gradation of the bed material, angle of attack of the approach flow to the pier, pier shape, bed configuration, and ice or debris jams. Dey (1997) adds the time of scouring as an additional parameter. Furthermore, Oliveto and Hager (2005) argue that the principal parameter influencing the scour process is the densimetric particle Froude number.

Akib et al. (2011) concluded that local scour on a doublerow pile integral bridge is higher than on a single-row pile integral bridge in a two-stage channel. Martin-Vide et al. (1998) examined the problem related to the interaction of two widths (pier and piles) that were set at different elevations with respect to the riverbed; a width-weighting method was recommended due to greater scouring when the riverbed is closer to the base of the pier.

The definition of time to scour equilibrium, adopted for a given test, plays an important role in the results obtained. The definition of time to equilibrium scour depth can affect the results so that the same experiment carried out under the same experimental conditions for a different timeframe can yield a different conclusion. Several researchers have come up with different definitions of time to equilibrium scour depth (Link, 2008).

In another study Melville and Raudkivi (1996) investigated local scour pattern at piers on slab footings and caissons. Furthermore, local scour around piers on piles has also been studied by a number of scholars (e.g. Ataie-Ashtiani and Beheshti, 2006; Ataie-Ashtiani et al., 2010; Coleman, 2005; Sheppard and Glasser, 2004; Tafarojnoruz et al., 2012;).

Many studies have been carried out to determine the maximum scour depth at bridge piers under clear water scour conditions. Researchers have studied the effect of flow intensity, flow shallowness, sediment coarseness, time, and velocity distribution on scour development (Diab et al., 2010; Hager and Unger, 2010; Jahangirzadeh et al., 2012; Karami et al., 2012; Mashahir et al., 2010; Tafarojnoruz et al., 2010).

Since using of semi-integral bridges is still relatively new, design parameters need to be established. One of these parameters is the effect of floods on semi-integral bridges. This is the prime concern for bridge designers since scour is one of the main causes of bridge failure.

In the present study, the effects of time on scour depth at semi-integral bridge piers and combined piles are investigated. In addition, the velocity distribution for semi-integral piers is examined. The scour depth with respect to distance is also presented. This research presents the experimental study on scouring mechanism at semi-integral bridge piers and these results can be used by researchers or engineers in future works.

\section{MATERIALS AND EXPERIMENTAL SETUP}

The experiments were conducted at the Hydraulic Laboratory of the University of Malaya. Experimental investigations were conducted in a flume of $16 \mathrm{~m}$ in length, $0.6 \mathrm{~m}$ width and $0.6 \mathrm{~m}$ depth flume of a fixed slope (Fig. 4).
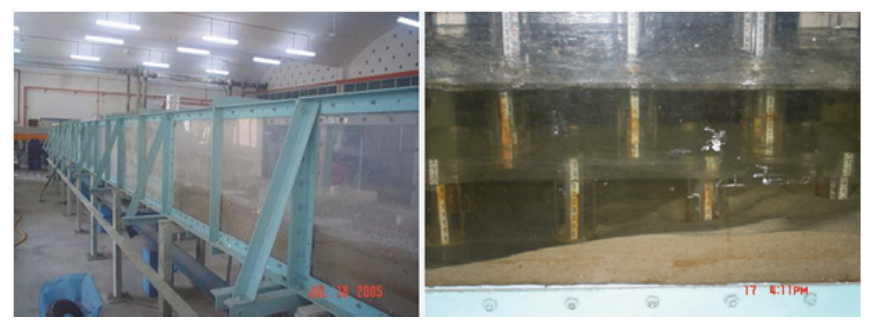

Fig. 4. Flume and bridge model in hydraulics laboratory.

At the end of the canal, there was a basin in which a triangular weir measured the flow discharge with an accuracy of 0.1 L/s. An adjustable tail gate was set up on the downstream of the canal to measure the water depth. The flow velocity components $(U)$ were measured near stream bed $(\mathrm{z}=0.5 \mathrm{~cm})$ by a three axis electronic current velocity meter with an accuracy of $\pm 1 \mathrm{~cm} / \mathrm{s}$. The velocity sampling raster is illustrated in Fig. 6 . The depth of scouring $\left(\mathrm{d}_{\mathrm{s}}\right)$ around piers and piles was measured and recorded by sand surface meter with an accuracy of \pm 0.5 $\mathrm{mm}$.

In order to measure time developing scour depth around piers and combined piles, sand surface meter was mounted on piers and recorded scour versus time.

At the end of each test, the water was carefully drained off from the flume to prevent any disturbance in the scour patterns. Then, the scour pattern and scour holes profiles around piers and piles were measured by a laser bed-profiler (LBP) with maximum error of $\pm 1 \mathrm{~mm}$ in width and $\pm 0.1 \mathrm{~mm}$ in depth. LBP recorded scour depth for each $1 \mathrm{~cm}$ in length and $1 \mathrm{~mm}$ in width in sampling area. In this sampling area, LBP recorded scour depth for 31200 points. The scour sampling area is illustrated in Fig. 5c. Finally, the scour contours were simulated using SURFER software.

All experiments involved the same time intervals for scour developing until final measure after 24 hours. Control block was used to control the initial sand level as the sampling area. It was positioned at the three quarter of the flume length from the upstream. The sampling area was filled with sand of $0.2 \mathrm{~m}$ depth. The recess was filled with uniform sediment with the mean particle sizes of $0.8 \mathrm{~mm}$ and specific gravity of 2.65 . Based on the study of Raudkivi and Ettema (1983), experiments can be run successfully for non-ripple forming sediments $\left(\mathrm{d}_{50} \geq\right.$ $0.7 \mathrm{~mm})$. The standard deviation of grain sizes was $\sigma_{\mathrm{g}}=1.25<$ 1.30 to eliminate the effect of non-uniformity of the bed material on scour depth (Raudkivi, 1998; Zarrati et al., 2010).

\section{SEMI-INTEGRAL BRIDGE DETAIL}

The semi-integral bridge model is a complex structure consisting of piers and piles. The model was made of Perspex material. Vertical depth scales were used to measure the scour depth at the piers and piles. Cylindrical Perspex pipes with diameter of $5 \mathrm{~cm}$ were used as pier models. According to Chiew and Melville (1987), the pier diameter should not be more than $10 \%$ of the channel width. The ratio $D / d_{50}=62.5 \geq$ 50 was used to exclude the effect of the grain size on the scour depth, where $D$ is the pier diameter and $d_{50}$ is the median size of 
the riprap grain. Fig. 5 shows the semi-integral bridge model with one row of piers and two row piles. Five discharges $\left(0.0106 \mathrm{~m}^{3} / \mathrm{s}, 0.0117 \mathrm{~m}^{3} / \mathrm{s}, 0.0134 \mathrm{~m}^{3} / \mathrm{s}, 0.0154 \mathrm{~m}^{3} / \mathrm{s}\right.$ and 0.0174 $\left.\mathrm{m}^{3} / \mathrm{s}\right)$ and five flow depths $(18 \mathrm{~cm}, 20 \mathrm{~cm}, 22 \mathrm{~cm}, 24 \mathrm{~cm}$ and 26 $\mathrm{cm})$ were applied by adjusting the valve on the main inlet pipe respectively. The water flow depth values were selected based on the recommendation of Chiew and Melville (1987) to eliminate the pier's effect on the rate of scour.
(Y) (Flow depth) $>3.5 \times$ pier diameter $(D)$, (Chiew and Melville, 1987).

Moreover, the discharges were selected to reach the $U / U_{c r}=$ 0.9 and satisfy clear water condition (flow intensity $=$ the ratio of the approaching flow velocity to the critical velocity for incipient motion for bed sediment movement $\left(U / U_{c r}\right)$ ). Throughout the experiments, the developments of scour around piers and piles were monitored.

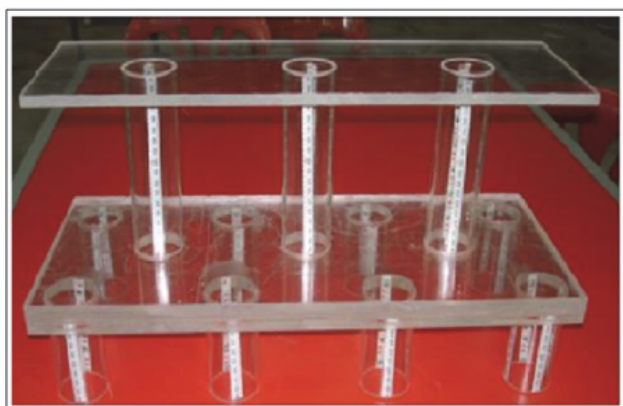

(a)

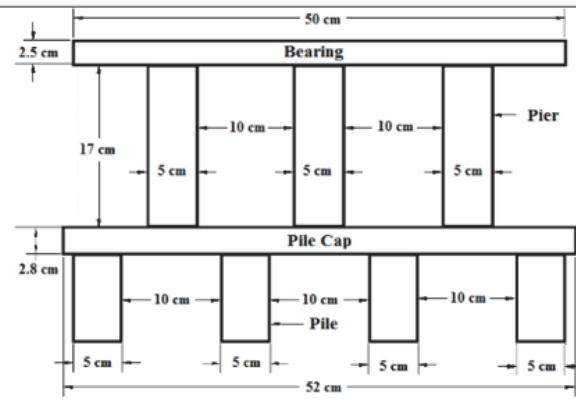

(b)

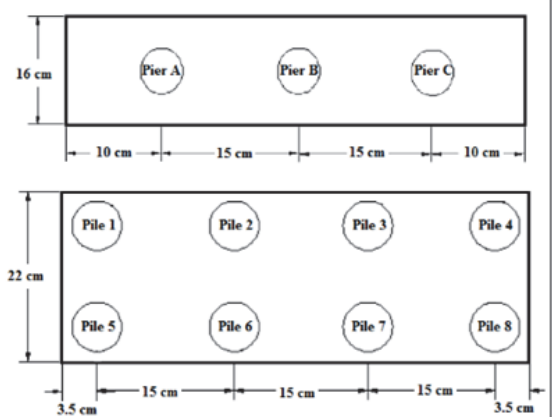

(c)

Fig. 5. (a) - Semi-integral bridge model; (b) - Pier and pile cross section; (c) - Plan of Pier and pile.

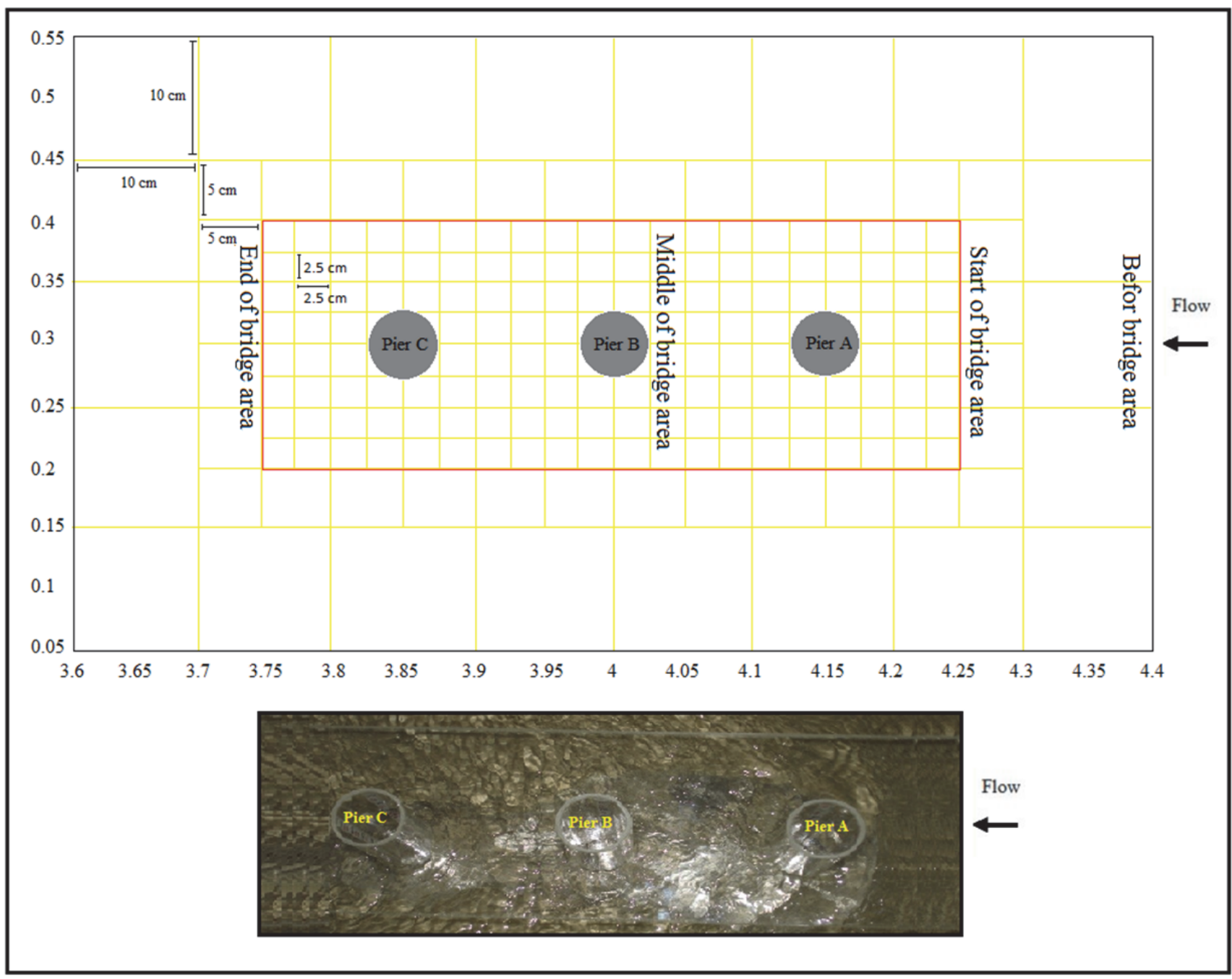

Fig. 6. Velocity sampling raster. 

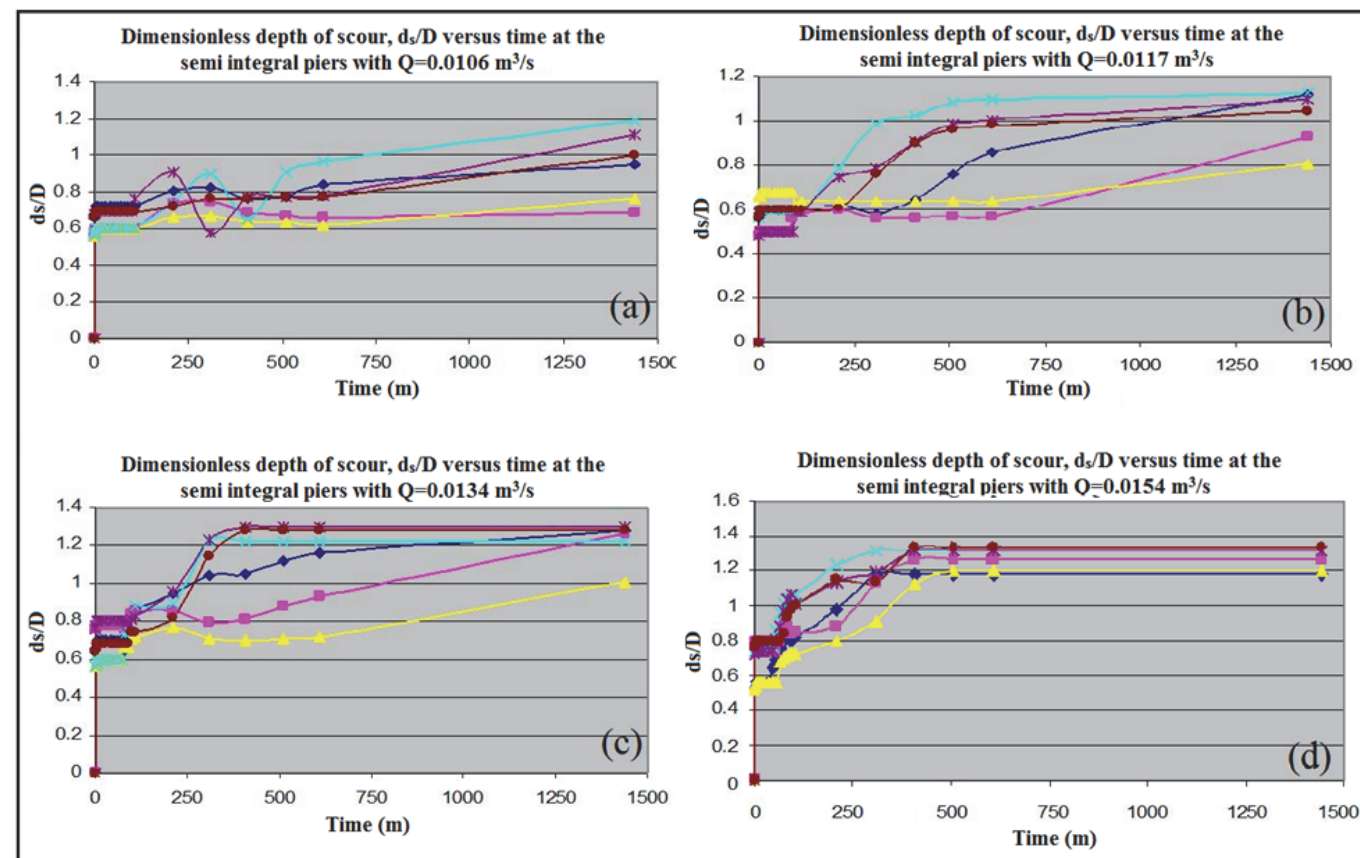

Dimensionless depth of scour, $d_{s} / D$ versus time at the semi integral piers with $Q=0.0174 \mathrm{~m}^{3} / \mathrm{s}$

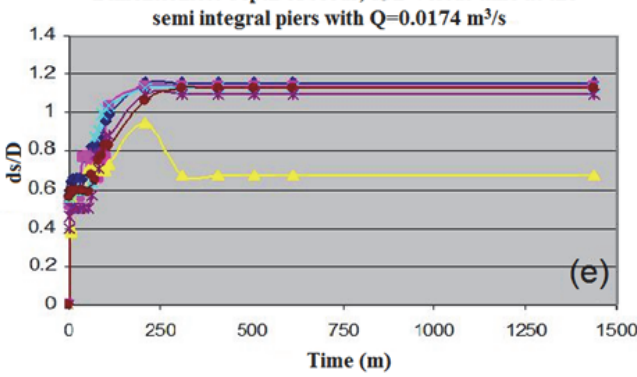

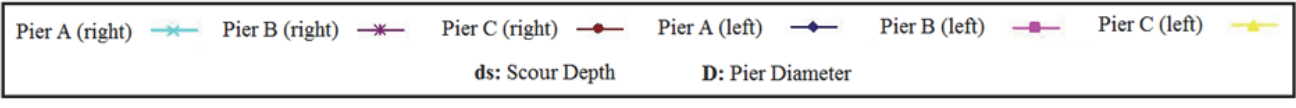

Fig. 7. Effect of time on local scour at piers sides (right and left).

\section{RESULT AND DISCUSSION \\ Effect of time on scour depth around semi-integral bridge piers}

The time development of scour depth was obtained for the semi-integral bridge piers (Fig. 7). For the flow discharge of $0.0106 \mathrm{~m}^{3} / \mathrm{s}$ and $0.0117 \mathrm{~m}^{3} / \mathrm{s}$ (Figs. $7 \mathrm{a}$ and $7 \mathrm{~b}$ ), the scour depth was still increasing after 24 hours. For the flow discharge of $0.0134 \mathrm{~m}^{3} / \mathrm{s}$ (Fig. 7c), the time when the scour depth reached the equilibrium state varied for the left and right side of the pier. At the right side, the equilibrium state was reached after 410 minutes. For the left side, the scour depth was still increasing after 24 hours. As flow discharge increased, the equilibrium state tended to occur at same time (Fig. 7d). The equilibrium state occurred earlier in case of flow discharge $0.0174 \mathrm{~m}^{3} / \mathrm{s}$ with flow depth $26 \mathrm{~cm}$ (Fig. 7e). It reached the equilibrium state after 310 minutes.

For flow discharge $0.0134 \mathrm{~m}^{3} / \mathrm{s}$ and $0.0174 \mathrm{~m}^{3} / \mathrm{s}$ (Figs. $7 \mathrm{c}$ and $7 \mathrm{e}$ ) at pier $\mathrm{C}$ on the left side and right side, the differences in scour depths were $14 \mathrm{~mm}$ and $24 \mathrm{~mm}$. This is due to the backwater effect: when the velocity increases, it must transport the sediment bed to the downstream bridge. Thus, due to the energy losses and the bridge crossing, the scour development was affected. There was fluctuation at the lower flow discharge due to the bed forms that occurred during the experiments.

\section{Effect of time on scour depth around combined piles}

The scour developments were also measured at combined piles. The scouring process around combined piles took place after the scour depth around the piers and pile cap reached an equilibrium state. Thus, there was no scouring around the combined piles in the initial stage.

The development of scour was averaged for each flow discharge. At the first pile, the scour depth reached the equilibrium state after a period of 510 minutes. The lowest discharges yielded the longest time to scouring (Fig. 8a). It took about 210 minutes before scour holes formed at the combined piles. The depth of scour increased over time for every point.

The time for scouring to occur started to reduce when the flow discharge increased. From 210 minutes to 90 minutes, the scouring process started to begin for flow discharge 0.0117 $\mathrm{m}^{3} / \mathrm{s}$ (Fig. $8 \mathrm{~b}$ ). The same trend was observed at every point where the depth of scour increased over time (Fig. 8c). Fig. 8d shows the scouring process tended to reach equilibrium time earlier when discharge was increased to $0.0154 \mathrm{~m}^{3} / \mathrm{s}$. The scouring process began after 90 minutes and 50 minutes. The earliest scouring process started after a period of 40 minutes (Fig. 8e). 

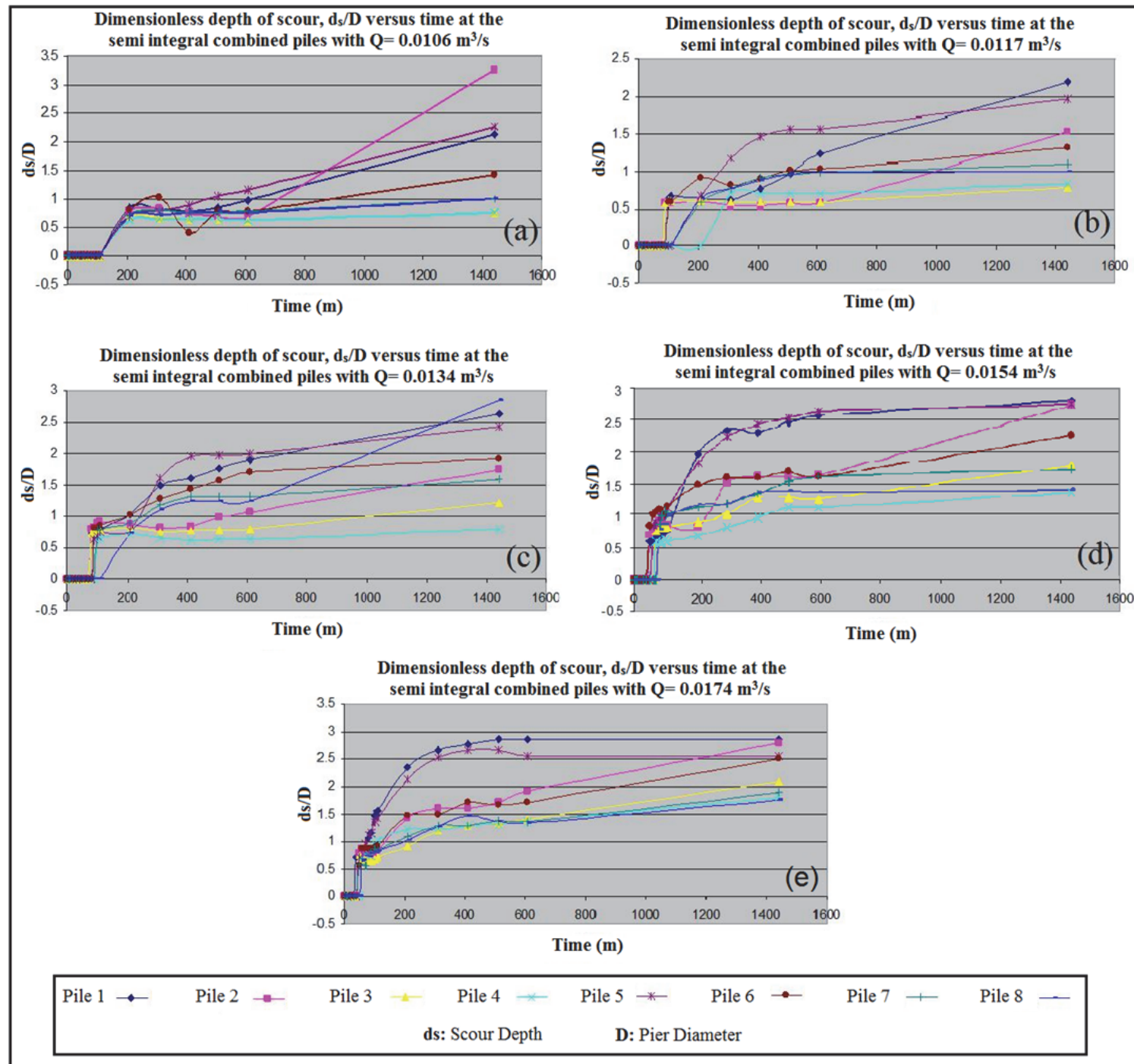

Fig. 8. Effect of time on local scour depth at combined piles.

\section{Scour depth with respect to distance}

As soon as the tests began, dunes were observed on the approaching bed. As the sediment transport continued, bed degradation took place, leading to an increase in flow depth and a corresponding reduction in flow velocity at the upstream. This affected the scour depth at the upstream. The development of scour at the upstream was higher than at the downstream. At the downstream, the sedimentation caused the increase in the base level and decreased the development of scour. Beds or dunes formed at the downstream due to the sediment supplied by the water flow.

To investigate the relationship of the scour depth with respect to its distance and position upstream and downstream, the scour depth contours with distance were plotted. Scour depth varied with distance as shown in Fig. 9. The scour depth at the upstream especially at the front of the semi-integral bridge was higher compared to the back of the semi-integral bridge that is at the downstream based on the contours map. This is due to the mechanism of sediment transport at the upstream. The approach flow scoured the bed sediment and transported it to the downstream. The degradation and aggradations of bed sediment process occurred in the channel.
At the lower flow rate, the scour depth was higher at the front pile and decreased at the back of the pile (Figs. 9a-9c). For the higher flow rate (Figs. 9d and 9e), the scour depth pattern was symmetrical on both sides upstream and downstream. This shows that the scour depth had not yet reached the equilibrium state. Besides the flow rate and the flow depth, sediment coarseness and particle size also affected the scour development.

\section{Velocity distribution for semi-integral piers}

Velocity distribution around the bridge also affected the development of scour for semi-integral bridge piers and combined piles. Significant changes in flow pattern at the bridge foundation were found.

Fig. 10 shows the variation of velocity distribution for semiintegral piers for every discharge with respect to the width of the flume. As it can be seen in Fig. 10, the velocity before bridge's area was lower than at the bridge area, and it increased as passing through bridge area, as a result of contraction due to bridge piers and piles. As it can be seen in this figure, the velocity continued to increase from the beginning of the bridge area to the end of the bridge area and reached its maximum amount at the end of bridge area. 


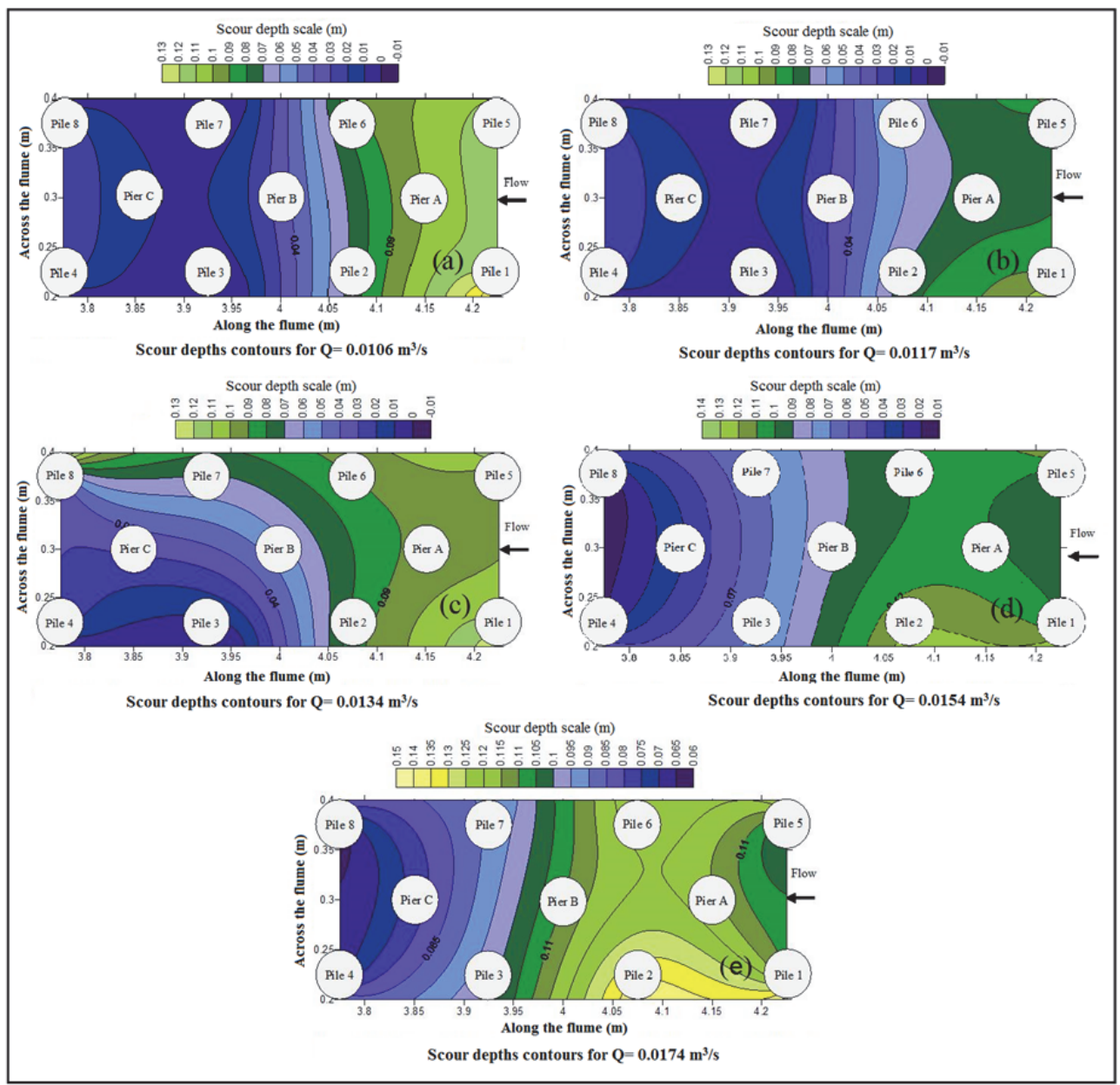

Fig. 9. The connection between the scour depth that occurs with respect to its distance and position of the upstream and downstream.

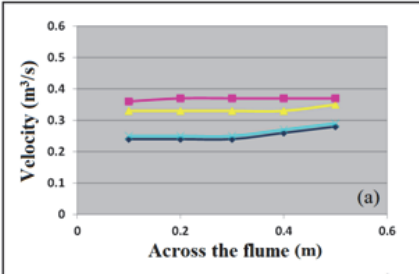

Velocity distribution for $Q=0.0106 \mathrm{~m}^{3} / \mathrm{s}$

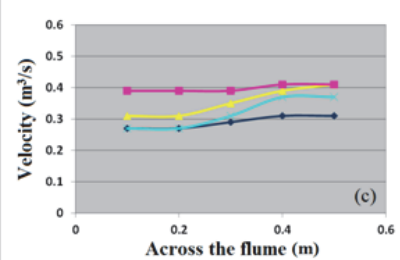

Velocity distribution for $Q=0.0134 \mathrm{~m}^{3} / \mathrm{s}$

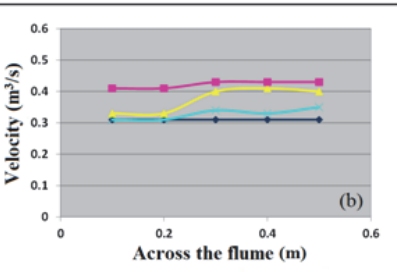

Velocity distribution for $Q=0.0117 \mathrm{~m}^{3} / \mathrm{s}$

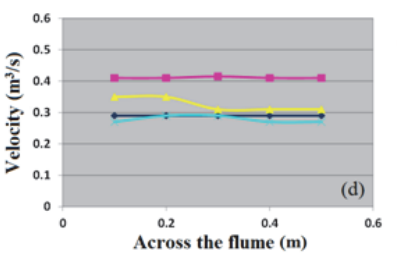

Velocity distribution for $Q=0.0154 \mathrm{~m}^{3} / \mathrm{s}$

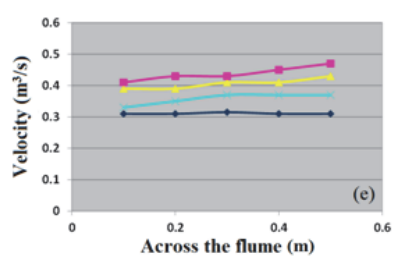

Velocity distribution for $Q=0.0174 \mathrm{~m}^{3} / \mathrm{s}$

Befor bridge area $\multimap \quad$ Start of bridge area $\longrightarrow \quad$ Middle of bridge area $\longrightarrow$ End of bridge area -

Fig. 10. Velocity distribution for semi-integral bridges piers with respect to the flume width. 


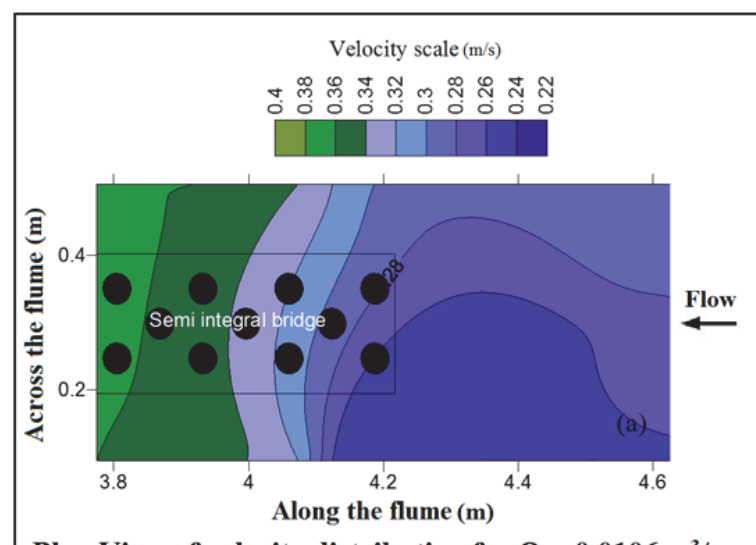

Plan View of velocity distribution for $Q=0.0106 \mathrm{~m}^{3} / \mathrm{s}$

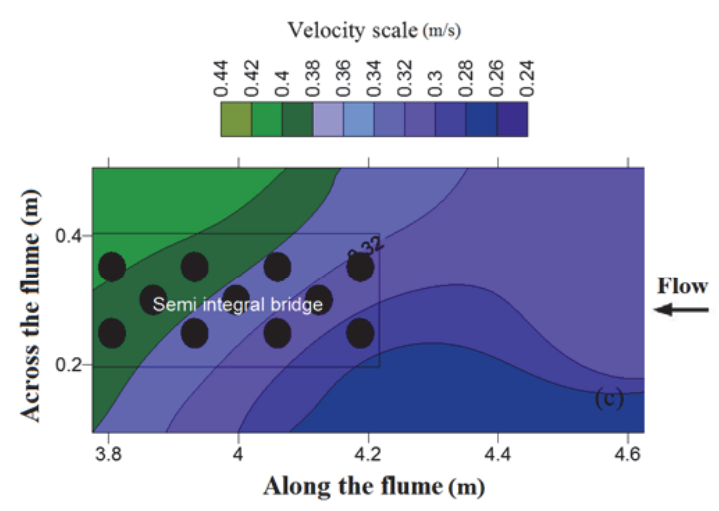

Plan View of velocity distribution for $Q=0.0134 \mathrm{~m}^{3} / \mathrm{s}$

Velocity scale $(\mathrm{m} / \mathrm{s})$

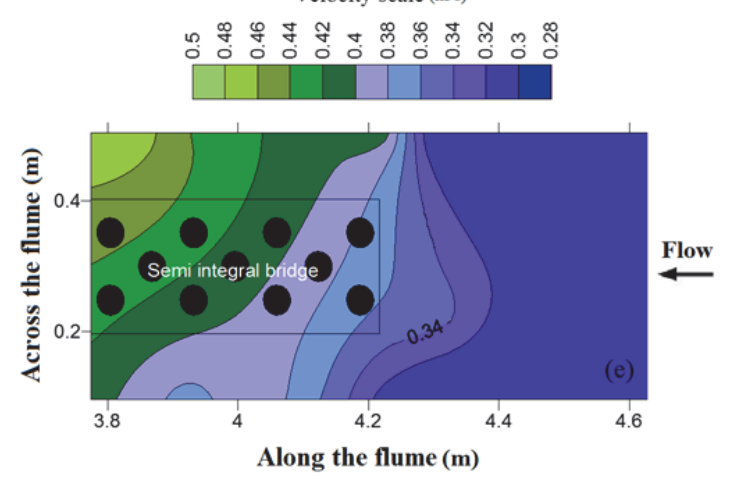

Plan View of velocity distribution for $Q=0.0174 \mathrm{~m}^{3} / \mathrm{s}$

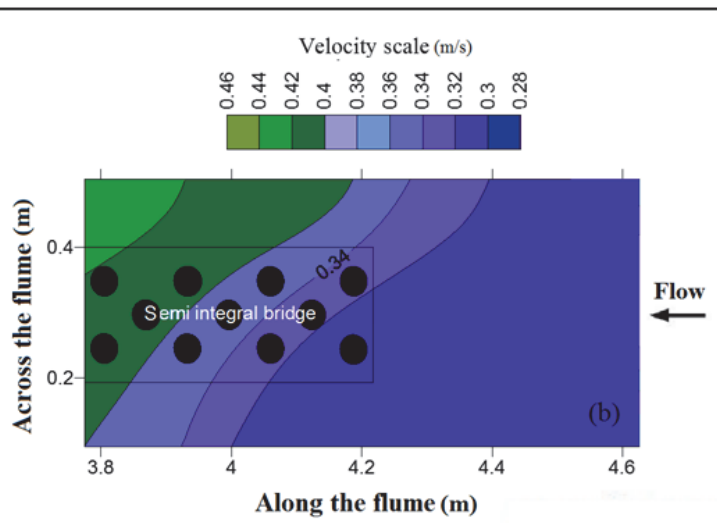

Plan View of velocity distribution for $Q=0.0117 \mathrm{~m}^{3} / \mathrm{s}$

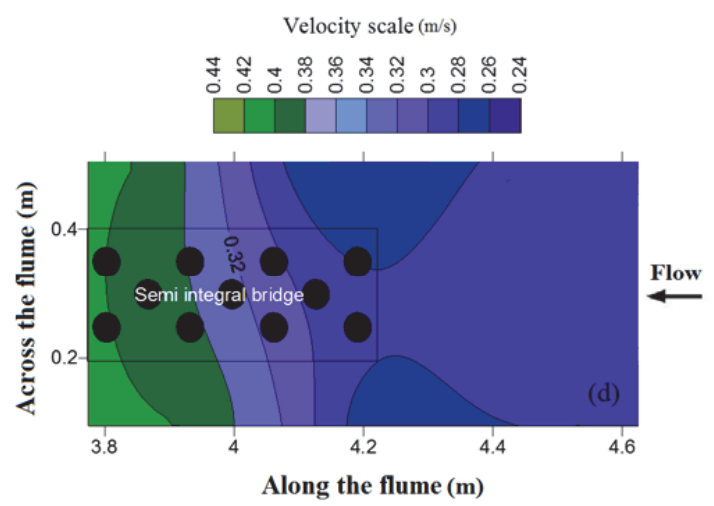

Plan View of velocity distribution for $Q=0.0154 \mathrm{~m}^{3} / \mathrm{s}$

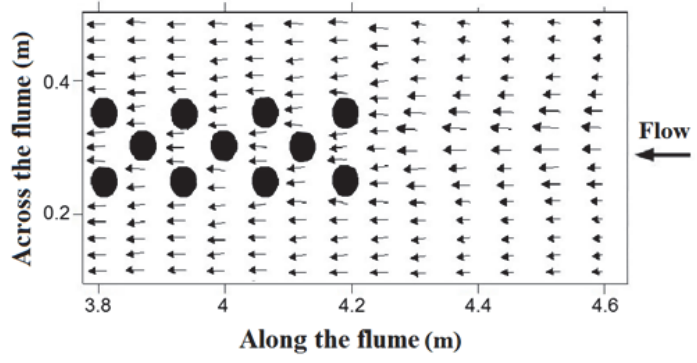

Plan View of velocity vectors

Fig. 11. Plan View of velocity distribution and velocity vectors along the flume.

Dunes were formed on the approaching and destabilized the stone, leading to degradation of the layer. This happens due to the sediment transport capacity exceeding sediment supply or a lowering of the base level. Sediment supply reach was provided from the watershed and from any erosion occurring in the waterway. Aggradations took place at the downstream of the channel. The aggradation raised the base level and increased the flow velocity gradually from the front of the bridge to the back of the bridge. This caused the total depth of scour at the downstream to decrease.

Fig. 11 shows the pattern of velocity distribution for every discharge along the flume. The velocity increased from the upstream to the downstream and passed through every pier in lines. The maximum velocity was obtained at the last pier. In each discharge, the velocity increased on the left and right side of the bridge nearly to equilibrium.

\section{CONCLUSIONS}

Based on laboratory experiments, this study examines the relationship between scour depth and various parameters, including the variation of flow velocity, distance, and time. Four types of discharges and four types of flow depths were used. From the results, the following conclusions can be drawn from this investigation:

1. The scour time development was greater for higher flow depth and flow discharge at semi-integral bridges. 
2. The equilibrium scour depth increased with approach flow depth around complex piers at semi-integral bridges. A similar trend was given in the plotted data with the research done by Melville and Coleman (2000).

3. Velocity distribution also affects the scour development at semi-integral bridges. Velocity decelerated when approaching the bridge but increased from upstream to downstream.

4. The scour depth varied with distance. The scour development at the upstream was higher compared to the downstream before it reaching the equilibrium state. When it reached equilibrium, the scour depths were symmetrical at the upstream and downstream at semi-integral bridges.

Acknowledgement. Financial support by the High Impact Research grants from the University of Malaya and Ministry of Education (UM.C/625/1/HIR/116 and UM.C/625/1/HIR/MOHE/ENG/61) are gratefully acknowledged.

\section{REFERENCES}

Akib, S., Mohammadhassani, M., Jahangirzadeh, A. 2014. Application of ANFIS and LR in prediction of scour depth in bridges. Computers \& Fluids, 91, 77-86.

Akib, S., Fayyadh, M. M., Othman, I., 2011a. Structural behaviour of a skewed integral bridge affected by different parameters. J. Road Bridge Eng., 6, 2, 107-114.

Akib, S., Othman, F., Sholichin, M., Fayyadh, M., Shirazi, S. M., Primasari, B., 2011b. Influence of flow shallowness on scour depth at semi-integral bridge piers. Adv. Mater. Res., 243-249, 4478-4481.

Fayyadh, M.M., Akib, S., Othman. I., A.Razak, H., 2011c. Experimental investigation and finite element modelling of the effects of flow velocities on a skewed integral bridge. Simulation Modelling Practice and Theory, 19, 1975-1810.

Akib, S., Fayyadh, M. M., Shirazi, S. M., Primasari, B., \& Idris, M. F. 2011d. Innovative countermeasure for integral bridge scour. Int. J. Phy. Sci, 6(21), 4883-4887.

Akib, S., Jahangirzadeh, A., Wei, L.H., Shirazi, S.M, Rahman, S., 2012. Experimental study on the skewed integral bridge by using crushed concrete geobags as scour protection. In: Proceeding of the 6th International Conference on Scour and Erosion, 27-31 August, Paris, France.

Ataie-Ashtiani, B., Beheshti, A., 2006. Experimental investigation of clear-water local scour at pile groups. J. Hydraul. Eng., 132, 10, 1100-1104.

Ataie-Ashtiani, B., Baratian-Ghorghi, Z., Beheshti, A., 2010. Experimental investigation of clear-water local scour of compound piers. J. Hydraul. Eng., 136, 6, 343-351.

Biddle, A.R., Iles, D.C., Yandzio, E., 1997. Integral Steel Bridges: Design Guidance. The Steel Construction Institute, ASCOT, Berkshire, UK.

Chiew, Y.M., Melville, B.M., 1987. Local scour around bridge piers. J. Hydraul. Res., 25, 1, 15-26.

Coleman, S.E., 2005. Clearwater local scour at complex piers. J. Hydraul. Eng., 131, 4, 330-334.

Deng, L., Cai, C.S., 2010. Bridge scour: prediction, modeling, monitoring, and countermeasures-review, Pract. Periodical Struct. Design Constr., 15, 2, 125-134.

Dey, S., 1997. Local scour at piers, part 1: A review of development of research. Int. J. Sediment Res., 12, 2, 23-46.

Diab, R., Link, O., Zanke, U., 2010. Geometry of developing and equilibrium scour holes at bridge piers in gravel. Can. J. Civil Eng., 37, 4, 544-552.
England, G.L., Tsang, N.C.M., Bush, D.I., 2000. Integral Bridges: A Fundamental Approach to the Time-Temperature Loading Problem. Telford, Thomas Limited.

Ghodsian, M., Vaghefi, M., 2009. Experimental study on scour and flow filed in a scour hole around a T-shape spur dike in a $90^{\circ}$ bend. Int. J. Sediment Res., 24, 2, 145-158.

Hager, W., Unger, J., 2010. Bridge pier scour under flood waves. J. Hydraul. Eng., 136, 10, 842-847.

Heidarpour, H., Afzalimehr, H., Izadinia, E., 2010. Reduction of local scour around bridge pier groups using collars. Int. J. Sediment Res., 25, 4, 411-422.

Jahangirzadeh, A., Akib, S., Ismail, Z., Kamali, B., Kakouei, M., Behnia, A., 2012. Determination of Rectangular Collar Dimensions for Reducing Scour around Bridge Pier. In: Proceeding of the 6th International Conference on Scour and Erosion, 27-31 August, Paris, France.

Karami, H., Basser, H., Ardeshir, A., Hosseini, S.H., 2012. Verification of numerical study of scour around spur dikes using experimental data. Water and Environment Journal, 49, 1-1.

Lagasse, P.F., Clopper, P.E., Zevenbergen, L.W., Girard, L.W., 2007. Countermeasures to protect bridge pier from scour. NCHRP Report-593. Transportation research board, Washington D.C., United States.

Lagasse, P.F., Zevenbergen, L.W., Schall, I.D., and Clopper, P.E., 2001. Bridge scour and stream instability countermeasures. Hydraulic Engineering, Circular No. 23 (HEC-23) Second edition, FHWANH1 01-003. Federal highway administration, Washington, D.C.

Link, O., Pfleger, F., Zanke, U., 2008. Characteristics of developing scour-holes at a sand embedded cylinder. Int. J. Sediment Res., 23, 3, 258-266.

Martin-Vide, J.P., Hidalgo, C., Bateman, A., 1998. Local scour at pier bridge foundation. J. Hydraul. Eng., 124, 4, 439-442.

Mashahir, M.B., Zarrati, A.R., Mokallaf, E., 2010. Application of riprap and collar to prevent scouring around rectangular bridge piers. J. Hydraul. Eng., 136, 3, 183-187.

Melville, B.W., 2008. The physics of local scour at bridge piers. In: Proceeding of the 4th International Conference on Scour and Erosion, 5-7 November, Tokyo, Japan.

Melville, B. W., Coleman S. E., 2000. Bridge, Water Resources. Publications LLC, Littleton, Colorado.

Melville, B.W., Raudkivi, A.J., 1996. Effect of foundation geometry on bridge pier scour. J. Hydraul. Eng., 114, 10, 203-209.

Oliveto, G., Hager, W.H., 2005. Further results to timedependent local scour at bridge elements. J. Hydraul. Eng., 131, 2, 97-105.

Pagliara, S., Carnacina, I., 2010. Temporal scour evolution at bridge piers: Effect of wood debris roughness and porosity. J. Hydraul. Res., 48, 1, 3-13.

Picek, T., Havlík, A., Mattas, D., 2004. Pressure flow and overflow bridges. J. Hydrol. Hydromech., 52, 3, 185-192.

Raudkivi, A.J., 1998. Loose Boundary Hydraulics. A.A. Balkema, Rotterdam, The Netherlands.

Raudkivi, A.J., Ettema, R., 1983. Clear-water scour at cylindrical piers. J. Hydraul. Eng., 109, 3, 339-350.

Sheppard, D.M., Glasser, T., 2004. Sediment scour at piers with complex geometries. In: Proceeding of the 2nd International Conference on Scour and Erosion, 14-17 November, Singapore.

Tafarojnoruz, A., Gaudio, R., Dey, S., 2010. Flow-altering countermeasures against scour at bridge piers: a review. J. Hydraul. Res., 48, 4, 441-452. 
Tafarojnoruz, A., Gaudio, R., Calomino, F., 2012. Bridge pier scour mitigation under steady and unsteady flow conditions. Acta Geophys., 60, 4, 1076-1097.

Zarrati, A.R., Nazariha, M., Mashahir, M.B., 2006. Reduction of local scour in the vicinity of bridge pier group using collars and riprap. J. Hydraul. Eng., 132, 2, 154-162.

Note: Colour version of Figures can be found in the web version of this article.
Zarrati, A.R., Chamani, M.R., Shafaie, A., Latifi, M., 2010. Scour countermeasures for cylindrical piers using riprap and combination of collar and riprap. Int. J. Sediment Res., 25, 313-322.

Received 30 May 2013 Accepted 30 January 2014 